\title{
AL BARIK (TURORIAL GAMBAR GRAFIK): SUATU MEDIA PEMBELAJARAN BERBASIS ARTICULATE STORYLINE 2
}

\author{
Ryan Angga Pratama \\ Program Studi Pendidikan Matematika, FKIP Universitas Balikpapan \\ Jl. Pupuk Raya, Balikpapan \\ Email: ryan.angga@uniba-bpn.ac.id
}

\begin{abstract}
ABSTRAK
Penelitian ini termasuk dalam kategori penelitian dan pengembangan ( R \& D) dengan tiga tahapan utama yang dimodifikasi dari Borg \& Gall (1989), yakni : 1) Pendahuluan dan Perencanaan, 2) Pengembangan Produk Awal, dan 3) Pelaksanaan (Validasi, Revisi, serta Uji Coba I dan II). Dalam pelaksanaannya, media pembelajaran Al Barik (Turorial Gambar Grafik) terlebih dahulu divalidasi oleh 1 ahli media, 1 ahli materi, dan 1 praktisi/guru, yang selanjutnya direvisi dan diujicobakan dalam lingkup skala kecil dengan subjek 8 siswa les privat peneliti dan skala besar dengan subjek 31 siswa di SMP Patra Dharma 2 Balikpapan. Adapun metode yang digunakan dalam pengumpulan data adalah wawancara, studi dokumentasi, dan angket yang telah divalidasi oleh ahli bahasa dan materi. Pada penelitian ini diperoleh hasil jika ditinjau berdasarkan tingkat kevalidan, kepraktisan, dan efektivitasnya; diperoleh hasil sebagai berikut : Al Barik (Turorial Gambar Grafik) Valid dengan rata-rata persentase 87,35\%, Praktis dengan persentase 81,53\%, dan Efektif dengan sumbangan keberhasilan penggunaan media tersebut pada uji coba sebesar 90,83\% (skala kecil) dan $88,13 \%$ (skala besar). Selain itu, berdasarkan capaian hasil belajar siswa juga menunjukkan ratarata di atas 75 , meskipun terdapat 3 siswa pada uji coba skala besar yang skor pencapaiannya tepat di angka 75.
\end{abstract}

Kata Kunci: Media pembelajaran, Al Barik (Turorial Gambar Grafik)

\begin{abstract}
This research belongs to the category of research and development (R \& D) with three main stages modified from Borg \& Gall (1989), namely: 1) Introduction and Planning, 2) Initial Product Development, and 3) Implementation (Validation, Revision, Experiment I and Experiment II). In its implementation, the media of Al Barik (Turorial Gambar Grafik) was first validated by 1 media expert, 1 material expert, and 1 practitioner / teacher, which was further revised and tested in small scope with subject of 8 students of private course and large scale with subject 31 students in SMP Patra Dharma 2 Balikpapan. The methods used in data collection are interviews, documentation studies, and questionnaires that have been validated by linguists and materials experts. In this study the results obtained when reviewed based on the level of validity, practicality, and effectiveness; the following results are obtained: Al Barik (Turorial Gambar Grafik) Valid with average percentage $87,35 \%$, Practical with percentage of $81,53 \%$, and Effective with success contribution of media usage at trial 90,83\% (small scale ) and $88,13 \%$ (large scale). In addition, based on student achievement outcomes also showed an average above 75, although there were 3 students on largescale trials whose achievement scores were precisely at 75 .
\end{abstract}

Keywords: Learning media, Al Barik (Turorial Gambar Grafik) 


\section{Pendahuluan}

Matematika merupakan ilmu universal yang mendasari perkembangan teknologi modern, berperan penting dalam berbagai disiplin ilmu, dan mengembangkan daya pikir manusia. Besarnya peranan tersebut, menjadikan matematika sebagai mata pelajaran wajib di sekolah, dan perlunya penguasaan konsep yang kuat sejak dini, serta dapat menumbuhkan kemampuan siswa dalam berpikir logis, analitis, sistematis, kritis, kreatif, dan bekerja sama (Puspitasari \& Hardini, 2012; Pratama, 2017). Namun, pada kenyataannya, sebagian besar dari siswa masih saja menganggap matematika sebagai mata pelajaran yang tidak menyenangkan, serta materinya yang terkesan sulit dan abstrak untuk dipahami. Hal inilah yang berpotensi menjadi penyebab utama kesulitan belajar mereka.

Berdasarkan hasil wawancara yang dilakukan pada Agustus 2017 terhadap beberapa siswa kelas VIII di SMP Patra Dharma 2 Balikpapan, diketahui bahwa mereka masih mengalami kesulitan dalam belajar matematika, khususnya pada materi Persamaan Garis Lurus. Hal ini mungkin dikarenakan pada materi sebelumnya, yakni Operasi Aljabar ataupun Relasi dan Fungsi, siswa masih menganggap abstrak dan sulit menerapkan konsep materi prasyarat tersebut pada materi Persamaan Garis Lurus. Menurut mereka pula, penyampaian guru di sekolah masih monoton, dan bahkan ada pula guru yang memberi latihan soal setelah itu ditinggal begitu saja, sehingga banyak diantara mereka yang kurang dan bahkan tidak memahami materi Persamaan Garis Lurus dengan baik.

Materi Persamaan Garis Lurus merupakan materi lanjutan dari Operasi Aljabar serta Relasi dan Fungsi. Begitu pentingnya materi ini, sehingga pemahaman terhadap materi ini sangatlah mutlak diperlukan sejak dikenalkan dan diajarkan di tingkat Sekolah Menengah Pertama. Tidak hanya memahami persamaan garis lurus, pada materi ini siswa juga dituntut untuk mampu mengembangkan aspek psikomotoriknya dalam hal menggambar grafik fungsi atau grafik persamaan garis lurus yang ada. Namun demikian, beberapa hasil penelitian juga menunjukkan bahwa siswa kesulitan dalam menyelesaikan soal aljabar fungsi pada pokok bahasan menentukan bentuk fungsi dan menggambar grafik fungsi tersebut (Narullita \& Masduki, 2016). Selain itu, siswa juga mengalami kesulitan dalam menggambar grafik dari persamaan garis lurus, menentukan gradien, dan menentukan persamaan dari suatu grafik garis lurus (Farihah, 2015). 
Melihat berbagai permasalahan pembelajaran yang ada, guru memegang peranan yang sangat penting dalam proses pembelajaran matematika di sekolah. Menyelenggarakan proses pembelajaran matematika yang baik dan bermutu di sekolah merupakan suatu keharusan yang tidak dapat ditawar lagi. Keberhasilan pembelajaran matematika didukung oleh kemahiran guru dalam melaksanakan aktivitas pengajaran serta kesadaran peserta didik dalam mengikuti aktivitas pembelajaran. Oleh karena itu, dalam pembelajaran, guru harus memiliki kemampuan yang mumpuni di bidang strategi maupun model pembelajaran yang bervariasi. Menurut Darmawan (2012), sebagai upaya untuk meningkatkan mutu atau kualitas pendidikan, serta dalam rangka menghadapi tantangan global, salah satunya dengan melakukan pembelajaran berbasis teknologi, yakni dengan berinovasi menggunakan media pembelajaran berbasis komputer dengan memanfaatkan hardware maupun software yang ada.

Proses belajar mengajar merupakan proses komunikasi, yakni penyampaian pesan dari pengantar ke penerima (Sanjaya, 2012; Daryanto, 2010; Munadi, 2013). Oleh karenanya, untuk memudahkan penyampaian dan penafsiran terhadapat materi yang diberikan oleh guru kepada siswa, diperlukanlah suatu media pembelajaran. Penggunaan komputer sebagai media pembelajaran juga memungkinkan terjadinya pembelajaran dengan menumbuhkan kemandirian siswa sehingga mereka akan mengalami proses belajar yang jauh lebih bermakna (Rusman, 2012), serta pembelajaran pun menjadi lebih efektif dan efisien dibanding pembelajaran yang konvensional (Serin, 2011). Adanya keistimewaan inilah, guru seharusnya tidak perlu lagi khawatir. Dalam penggunaannya, terdapat beberapa model pembelajaran berbantuan komputer yang menarik, salah satunya adalah model tutorial (Darmawan, 2012).

Model tutorial berbasis komputer ini menyediakan rancangan pembelajaran yang kompleks yang berisi materi pembelajaran, latihan yang disertai umpan balik (Sanjaya, 2012; Darmawan, 2012). Adapun tujuan digunakannya model ini adalah agar pembelajaran matematika tidak seperti biasanya, menjadikan suasana menyenangkan, serta membuat siswa untuk belajar mandiri dengan menyaksikan tutorial yang ada. Sehingga, dengan perasaan senang, diharapkan siswa lebih mudah memahami materi pelajaran yang diberikan dan juga mereka akan merasa nyaman dan tertarik dalam belajar dan menghindarkan dari kegiatan pembelajaran yang menjenuhkan. Kachepa \& Jere (2014) mengungkapkan bahwa teknologi dapat digunakan oleh guru 
maupun orang tua dalam mengenalkan matematika secara istimewa. Hal ini tentu akan memberikan sesuatu yang baru dibandingkan dengan pembelajaran rutin di kelas.

Melihat betapa berpotensinya teknologi komputer sebagai media pembelajaran dalam meningkatkan kualitas pembelajaran dan betapa penting mengembangkan psikomotorik siswa dalam menggambar graafik dari Persamaan Garis Lurus, maka dalam penelitian ini akan dilakukan suatu pengembangan produk media pembelajaran yang dapat dimanfaatkan untuk mendukung kegiatan belajar mengajar dan menarik minat atau motivasi belajar siswa. Adapun produk tersebut berupa media tutorial berbasis Articulate Storyline 2 yang diberi nama Al Barik (Tutorial Gambar Grafik). Articulate sendiri merupakan salah satu aplikasi yang baru diperkenalkan pada tahun 2001. Keahlian dalam membuat presentasi terkait dengan kemampuan teknis dan kemampuan seni, serta kolaborasi kedua kemampuan ini dapat menghasilkan presentasi tutorial yang menarik (Kholifah \& Santosa, 2016).

Articulate Storyline adalah perangkat lunak yang difungsikan sebagai media komunikasi atau presentasi. Media pembelajaran menggunakan software ini tidak kalah menarik dengan media interaktif lainnya (Purnama \& Asto, 2014). Articulate digunakan dalam mempresentasikan informasi dengan tujuan tertentu (sesuai tujuan pengguna). Keahlian dalam membuat presentasi terkait dengan kemampuan teknis dan kemampuan seni, serta kolaborasi kedua kemampuan ini dapat menghasilkan presentasi yang menarik. Sehingga dapat menarik peserta yang mengikuti presentasi tersebut.

Peneliti menggunakan software Articulate Storyline dikarenakan software ini masih jaarang digunakan dalam penelitian dan dipakai oleh guru dibandingkan dengan media berbasi PowerPoint ataupun Adobe Flash. Adapun kriteria dalam menilai software media pembelajaran yang digunakan atau dikembangkan peneliti menurut Arsyad (2011) adalah sebagai berikut :

1. Kualitas isi dan tujuan; meliputi ketepatan, kepentingan, kelengkapan, keseimbangan, minat/perhatian, keadilan, dan kesesuaian dengan situasi siswa

2. Kualitas instruksional; meliputi pemberian kesempatan dan bantuan belajar siswa, kualitas memotivasi, fleksibilitas instruksional, hubungan dengan program pembelajaran lainnya, kualitas sosial instruksional, kualitas tes dan penilaian, memberi dampak bagi 
siswa, serta dampak bagi guru dan pembelajarannya

3. Kualitas teknis; meliputi keterbacaan, kemudahan penggunaan, kualitas tampilan dan penayangan jawaban, kualitas pengelolaan program, dan pendokumentasian

Adapun media pembelajaran yang dikembangkan berupa file aplikasi yang dapat digunakan oleh guru dalam pembelajaran di kelas menggunakan komputer atau laptop.

\section{Metode Pengembangan}

Jenis penelitian ini termasuk dalam kategori penelitian dan pengembangan (Research and Development) yang didefinisikan sebagai metode penelitian yang digunakan untuk menghasilkan produk, desain, dan proses tertentu dan menguji keefektifan produk tersebut (Setyosari, 2013; Sugiyono, 2016). Adapun prosedur yang dilakukan peneliti sebagaimana diadaptasi dari siklus penelitian dan pengembangan Borg dan Gall (1989) sebagai berikut : 1) potensi dan masalah, 2) mengumpulkan informasi, 3) desain produk, 4) validasi desain, 5) perbaikan desain, 6) uji coba produk, 7) revisi produk, 8) ujicoba pemakaian, 9) revisi produk, 10) pembuatan produk masal (Setyosari, 2013; Sugiyono, 2016).
Berdasarkan siklus tersebut, peneliti merangkum dan memodifikasinya menjadi tiga tahapan utama, yakni :

\section{Pendahuluan dan Perencanaan}

Pada tahapan ini, dilakukan kegiatan yang meliputi studi literatur, yakni mencari dan menemukan bahan kajian pustaka, penelitian yang relevan berkaitan dengan media presentasitutorial, konsep dan landasan teoritis untuk memperkuat produk yang akan dikembangkan, identifikasi permasalahan pembelajaran yang dialami guru, wawancara dengan beberapa siswa/i Sekolah Menengah Pertama terkait dengan kesulitannya menggambar grafik fungsi, serta kebutuhannya dalam belajar Persamaan Garis Lurus, mengkaji Silabus Matematika SMP, dan merangkumnya ke dalam catatan sebagai bahan dalam melakukan proses pengembangan produk pada tahap selanjutnya.

\section{Pengembangan Produk Awal}

Pada tahapan ini, dilakukan perencanaan dan perumusan tujuan khusus yang ingin dicapai dari media presentasi-tutorial yang akan dikembangkan, penentuan urutan bahan dan materi, serta uji ahli atau uji coba pada skala kecil. Penulis juga melakukan penerjemahan desain perencanaan media presentasi-tutorial 
Al Barik (Tutorial Gambar Grafik) yang akan dikembangkan ke bentuk tampilan sebenarnya, atau dengan kata lain dimulailah pengembangan format produk awal yang mencakup penyiapan bahan-bahan atau materi pembelajaran serta software yang akan digunakan untuk membuatnya, yakni Articulate Storyline 2 yang telah terinstall di Notebook dan siap digunakan untuk membuat media yang dimaksud sebagai produk awal. Selain itu, juga digunakan software pendukung lainnya seperti Adobe Photoshop, Paint, maupun Corel Draw yang berguna untuk mendesain gambar, foto ataupun background tampilan, serta teks yang akan disajikan.

\section{Pelaksanaan (Validasi, Revisi, dan Uji Coba)}

Validasi produk dilakukan oleh ahli media pembelajaran, ahli materi, serta praktisi/guru. Adapun desain validasinya adalah validasi isi (content validity) dimana kelompok ahli mengisi instrumen berupa angket dan memberi kritik atau saran terhadap produk yang dikembangkan agar selanjutnya dapat direvisi. Selanjutnya, uji coba dilakukan kepada pengguna untuk mengetahui kualitas produk yang dikembangkan. Subjek coba sekaligus penilai produk media presentasi-tutorial Al Barik (Tutorial
Gambar Grafik) adalah sekelompok siswa SMP/MTs/Sederajat di Balikpapan, dan pelaksanaan uji cobanya menggunakan desain OneShot Case Study.

a. Uji Coba I (Skala Kecil), dilaksanakan dengan melibatkan 8 siswa kelas VIII sebagai subjek. Adapun siswa/i tersebut merupakan murid les peneliti yang berasal dari berbagai sekolah. Adapun pengumpulan informasi dilakukan dengan menggunakan hasil angket yang kemudian dianalisis sebagai bahan masukan untuk dilakukan revisi produk.

b. Uji Coba II (Skala Besar), dilaksnakan di SMP Patra Dharma 2 Balikpapan yang melibatkan 31 siswa kelas VIII.

Adapun teknik pengumpulan data dilakukan dengan beberapa teknik, yaitu :

a. Wawancara; dilakukan terhadap Guru Matematika serta beberapa siswa dari SMP Patra Dharma 2 Balikpapan.

b. Studi Dokumentasi; untuk mengkaji beberapa literatur terkait, menggali data berupa catatan, foto, dan data lainnya sesuai fokus penelitian, serta langkah konkret serangkaian pelaksanaan pengembangan media presentasi- 
tutorial Al Barik (Tutorial Gambar Grafik).

c. Angket; disusun sesuai peran dan posisi subjek data yang terdiri dari angket untuk ahli media, ahli materi, praktisi/guru, serta angket untuk pengguna (siswa).

Berdasarkan tahapan penelitian dan pengembangan yang digunakan, jenis data yang diperoleh bersifat kuantitatif dan kualitatif. Data kuantitatif berupa skor yang diperoleh dari angket penilaian produk pengembangan untuk validator/ahli media, ahli materi, praktisi/guru, serta siswa yang disusun dengan Skala Likert. Selanjutnya, data kuantitatif yang diperoleh tersebut dihitung dengan teknik analisis data persentase yang dirumuskan sebagai berikut :

$$
P=\frac{\sum X}{N} \times 100 \%
$$

dimana :

$P \quad=$ persentase skor dari ahli

$N=$ skor maksimal

$\sum X \quad=$ jumlah skor jawaban dari ahli

(Arikunto, 2010).

Media presentasi-tutorial Al Barik (Tutorial Gambar Grafik) dikatakan berhasil jika dari hasil penilaian validator menunjukkan kategori "Valid" berdasarkan penilaian dari butir-butir angket dilihat dari aspek validitas. Adapun kriteria kevalidan yang ditetapkan sebagaimana pada tabel berikut:

Tabel 1. Kriteria Kevalidan Media Pembelajaran yang Dikembangkan

$\begin{array}{ccc}\begin{array}{c}\text { Persentase } \\ 75 \leq P\end{array} & \text { Kriteria } & \text { Valid } \\ \leq 100 & \begin{array}{c}\text { Keterangan } \\ \text { Layak/Tidak } \\ \text { Perlu Revisi }\end{array} \\ 50 \leq P<75 & \text { Cukup } & \text { Cukup } \\ & \text { Valid } & \begin{array}{c}\text { Layak/Revisi } \\ \text { Kecil }\end{array} \\ & & \text { Kurang } \\ 26 \leq P<50 & \text { Kurang } & \text { Layak/Revisi } \\ & \text { Valid } & \text { Besar } \\ & \text { Tidak } \\ P<26 & \text { Tidak } & \text { Tidak } \\ & \text { Valid } & \text { Layak/Revisi } \\ & & \text { Total }\end{array}$

dimana :

$P=$ persentase skor butir-butir angket dilihat dari aspek validitas

(diadopsi dari Arikunto, 2010).

Selanjutnya, media presentasi-tutorial Al Barik (Tutorial Gambar Grafik) dikatakan berhasil jika dari hasil penilaian validator menunjukkan kategori "Praktis" berdasarkan penilaian dari butir-butir angket dilihat dari aspek kepraktisan. Adapun kriteria kepraktisan sebagaimana pada tabel berikut : 
Tabel 2. Kriteria Kepraktisan Media Pembelajaran yang Dikembangkan

\begin{tabular}{|c|c|c|}
\hline Persentase & Kriteria & Keterangan \\
\hline $\begin{array}{l}75 \leq P \\
\leq 100\end{array}$ & Praktis & $\begin{array}{l}\text { Layak/Tidak } \\
\text { Perlu Revisi }\end{array}$ \\
\hline $50 \leq P<75$ & $\begin{array}{l}\text { Cukup } \\
\text { Praktis }\end{array}$ & $\begin{array}{c}\text { Cukup } \\
\text { Layak/Revisi } \\
\text { Kecil }\end{array}$ \\
\hline $26 \leq P<50$ & $\begin{array}{l}\text { Kurang } \\
\text { Praktis }\end{array}$ & $\begin{array}{c}\text { Kurang } \\
\text { Layak/Revisi } \\
\text { Besar }\end{array}$ \\
\hline$P<26$ & $\begin{array}{c}\text { Tidak } \\
\text { Praktis }\end{array}$ & $\begin{array}{c}\text { Tidak } \\
\text { Layak/Revisi } \\
\text { Total }\end{array}$ \\
\hline
\end{tabular}

dimana :

$P=$ persentase skor butir-butir angket

dilihat dari aspek kepraktisan

(diadopsi dari Arikunto, 2010).

Selanjutnya, untuk mengetahui tingkat efektivitas Al Barik (Tutorial Gambar Grafik), dapat dilihat berdasarkan skor pencapaian yang diperoleh dari hasil jawaban siswa atas soal-soal tantangan di game tersebut, dengan nilai minimal disesuaikan dengan Kriteria Ketuntasan Minimum (KKM) yang berlaku di kedua sekolah siswa tersebut, yakni 75 . Selanjutnya, diperlukan juga perhitungan angket siswa yang digunakan untuk mengetahui tanggapan dari mereka mengenai penggunaan Al Barik (Tutorial Gambar Grafik) dalam pembelajaran. Media presentasi-tutorial Al Barik (Tutorial Gambar Grafik) dikatakan berhasil jika dari hasil tanggapan siswa menunjukkan kategori "Efektif" berdasarkan penilaian dari butir-butir angket dilihat dari aspek keefektifan.
Adapun kriterianya disajikan pada tabel berikut :

Tabel 3. Kriteria Keefektifan Media Pembelajaran yang Dikembangkan

$\begin{array}{ccc}\begin{array}{c}\text { Persentase } \\ 75 \leq P\end{array} & \text { Kriteria } & \text { Keterangan } \\ \leq 100 & \text { Efektif } & \text { Layak/Tidak Perlu } \\ & \text { Revisi } \\ 50 \leq P<75 & \text { Cukup } & \text { Cukup } \\ & \text { Efektif } & \text { Layak/Revisi Kecil } \\ 26 \leq P<50 & \text { Kurang } & \text { Kurang } \\ & \text { Efektif } & \text { Layak/Revisi } \\ & & \text { Besar } \\ P<26 & \text { Tidak } & \text { Tidak } \\ & \text { Efektif } & \text { Layak/Revisi Total }\end{array}$

dimana :

$P=$ persentase skor butir-butir angket

dilihat dari aspek keefektifan

(diadopsi dari Arikunto, 2010).

\section{Hasil dan Pembahasan}

Penelitian ini dilaksanakan berdasarkan model penelitian dan pengembangan Borg \& Gall (1989) yang secara garis besar dimulai dari tahap pendahuluan dan perencanaan, pengembangan produk, serta pelaksanaan (validasi, revisi, dan uji coba produk). Adapun hasil dari pelaksanaan penelitian dan pengembangan ini adalah sebagai berikut:

a. Gambaran Umum Pembuatan $A l$ Barik (Tutorial Gambar Grafik)

Pengembangan produk dilakukan pada bulan September hingga Desember 2017. Pada tahapan ini, langkah pertama dalam mendesain media tutorial adalah membuat synopsis atau alur cerita dari media. 
Media pembelajaran ini bernama $A l$ Barik (Tutorial Gambar Grafik) yang berisi tentang materi Grafik Fungsi melalui video tutorial dan menu navigasi berisi contoh soal yang komunikatif, serta latihan soal yang menantang. Setelah rancangan atau desain media telah selesai, maka selanjutnya dilakukan pembuatan $\mathrm{Al}$ Barik (Tutorial Gambar Grafik) dengan Articulate Storyline 2.

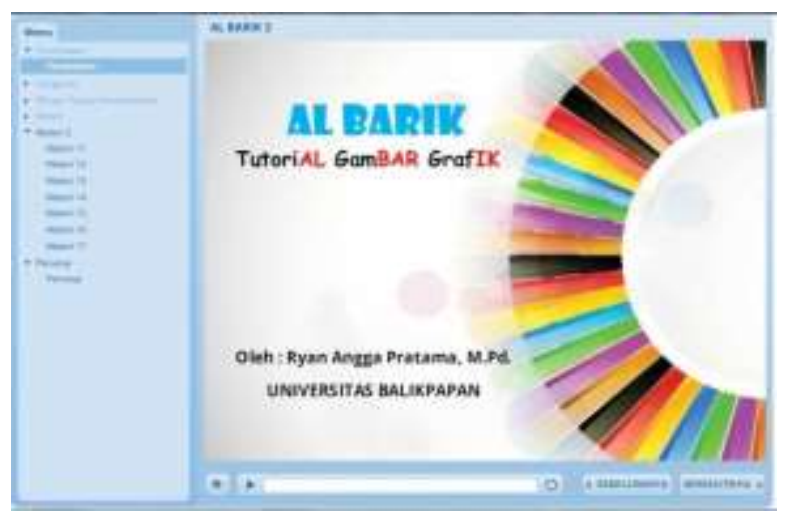

Gambar 1. Tampilan Awal Al Barik

(Tutorial Gambar Grafik)

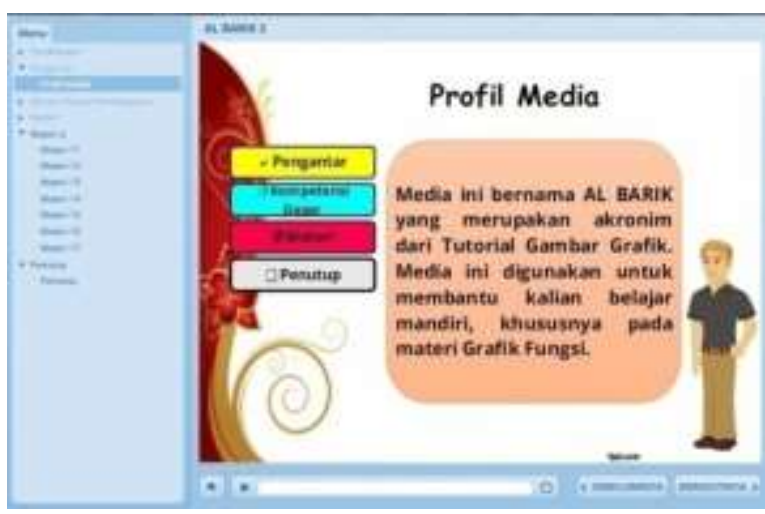

Gambar 2. Tampilan Menu Utama atau

Profil Media

Langkah selanjutnya dalam pembuatan media ini adalah membuat konten/isi dengan meletakkannya pada tiap-tiap scene, yang kemudian dilengkapi dengan trigger (semacam hyperlink) dari tiap-tiap scene tersebut. Selain membuat scene dan juga bagiannya yakni slide, peneliti juga mendesain layout dan background. Adapun trigger digunakan untuk menghubungkan tombol-tombol menu dan juga "berikutnya" dan "sebelumnya" sehingga alur berjalan sesuai desain.

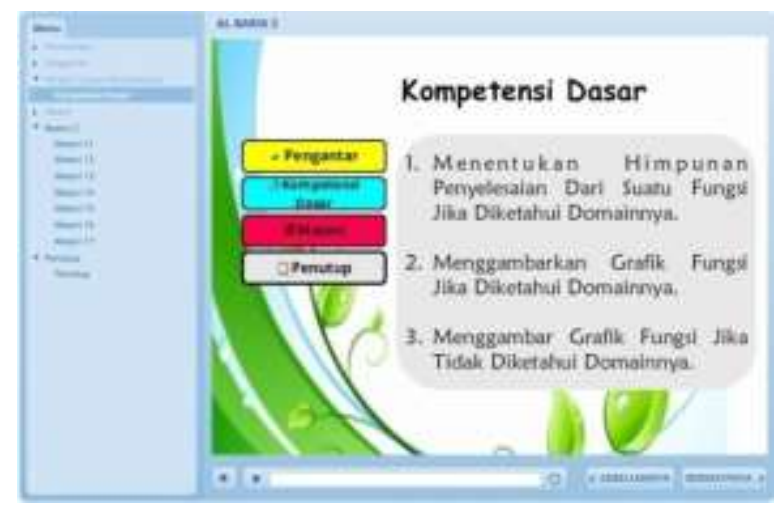

Gambar 3. Tampilan Kompetensi Dasar yang dipelajari siswa

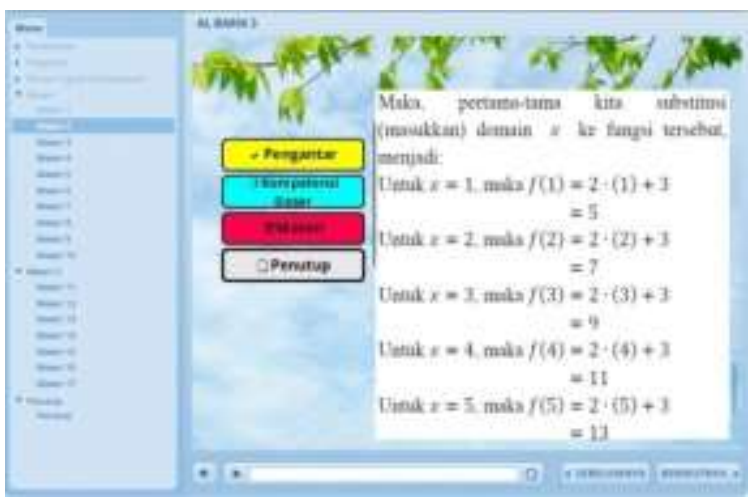

Gambar 4. Salah Satu Tampilan Materi 


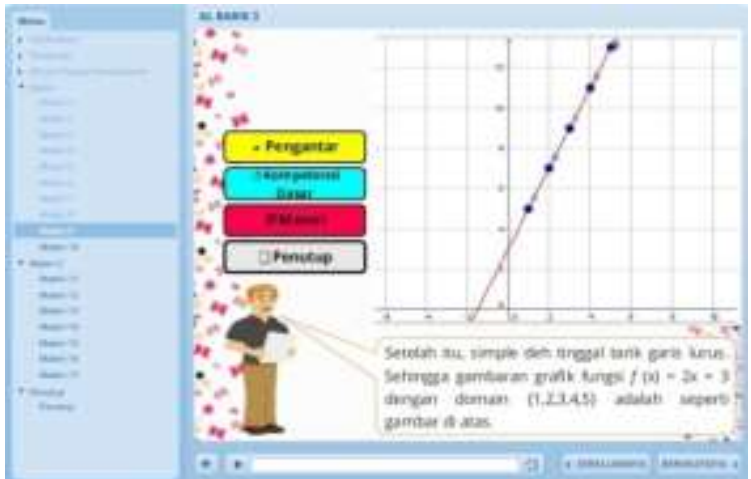

Gambar 5. Tampilan Grafik Fungsi yang ditutorialkan

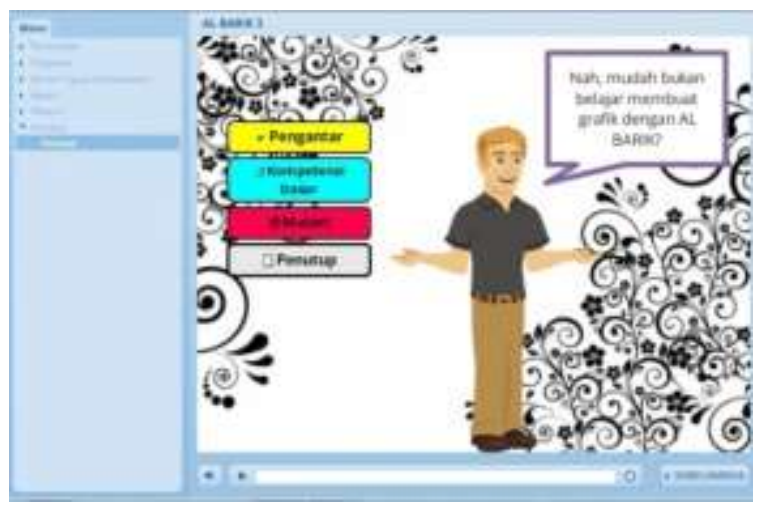

Gambar 6. Tampilan Penutup

Setelah semua komponen media pembelajaran dibuat, dilakukanlah percobaan berkali-kali dan perbaikan berkali-kali sampai tidak mengalami error dan dapat berjalan lancar dari awal sampai akhir. Setelah pembuatan media selesai, dilakukan kompilasi atau di-publish ke dalam bentuk file aplikasi (.exe).

b. Kelayakan Media Pembelajaran

Pada pengujian media presentasitutorial Al Barik (Tutorial Gambar Grafik) ini, divalidasi kelayakannya oleh ahli media, ahli materi, praktisi/guru, serta tanggapan dari siswa (pengguna). Selanjutnya, para ahli akan memberikan saran dan rekomendasi apabila media dirasa belum layak agar dilakukan revisi. Setelah direvisi, media yang dikembangkan dapat diujicobakan kepada para siswa, dimana tahapan uji coba dilakukan dua kali. Berdasarkan hasil penilaian kelayakan oleh para ahli, diperoleh hasil :

1) Hasil validasi dari seorang ahli media, yakni seorang pemenang lomba pembuatan Bahan Ajar Berbasis Articulate Storyline yang diadakan Dinas Pendidikan dan Kebudayaan kota Balikpapan pada bulan Agustus 2017 lalu. Dengan keahliannya, validator tersebut menilai media yang dikembangkan dengan menggunakan instrumen angket penilaian. Setelah dianalisis, hasil persentase validator tersebut adalah 93,04\% (layak). Adapun saran dari validator tersebut diantaranya perlunya ditambahkan 1 scene khusus untuk petunjuk penggunaan media.

2) Hasil validasi dari seorang ahli materi, yakni Guru Matematika SMP Patra Dharma 2 Balikpapan. Validator tersebut menilai media 
yang dikembangkan dengan sangat teliti. Setelah dianalisis, hasil persentase dari validator tersebut adalah $81,67 \%$ (layak). Namun, dengan catatan perlu ditambahkan lagi latihan soal berbentuk pilihan ganda agar pengukuran pemahaman siswa lebih baik.

3) Setelah divalidasi oleh ahli media dan ahli materi, media presentasitutorial Al Barik (Tutorial Gambar Grafik) juga di-review oleh seorang praktisi/guru, yakni Guru Komputer dari SMP Patra Dharma 2 Balikpapan. Validator tersebut menilai media pembelajaran yang dikembangkan dengan melihat aspek keterlaksanaan pembelajarannya. Setelah dianalisis, hasil persentase dari validator tersebut adalah $81,53 \%$ (layak). Adapun catatan dari validator tersebut diantaranya media yang dibuat sangatlah praktis karena memuat latihanlatihan soal yang memberikan kesempatan kepada siswa untuk tertantang belajaar secara mandiri

Selanjutnya, jika ditinjau berdasarkan penilaian dari butir-butir angket dilihat dari aspek validitasnya, media presentasi- tutorial Al Barik (Tutorial Gambar Grafik)

"valid" dengan rata-rata 87,35\%.

Jika ditinjau berdasarkan penilaian dari butir-butir angket dilihat dari aspek kepraktisannya, media presentasi-tutorial Al Barik (Tutorial Gambar Grafik) “praktis" dengan persentase $81,53 \%$.

Setelah divalidasi, media presentasitutorial Al Barik (Tutorial Gambar Grafik) direvisi berdasarkan saran dan catatan umum dari para ahli sebelum dilakukan uji coba. Selanjutnya, pada saat pelaksanaan uji coba, tanggapan siswa pun Sangat Baik. Selain itu, skor atau capaian hasil belajar mereka menunjukkan hasil yang baik. Berdasarkan skor capaian siswa pada media tersebut, seluruh siswa mendapat skor di atas 75 pada uji coba skala kecil. Sedangkan pada uji coba skala besar, 28 dari 31 siswa mendapat rata-rata skor di atas 75. Adapun saat pengujian, jika ditinjau berdasarkan penilaian dari butirbutir angket dilihat dari aspek efektivitasnya, media presentasi-tutorial $A l$ Barik (Tutorial Gambar Grafik) "efektif" dengan sumbangan keberhasilan penggunaan media tersebut pada uji coba sebesar 90,83\% (skala kecil) dan 88,13\% (skala besar).

Perlu diketahui pula, pada saat pelaksanaan uji coba pun peneliti melihat bahwa siswa sangatlah antusias dalam belajar secara interaktif di depan laptop masing-masing. Beberapa siswa juga 
merasa kesulitan pada latihan soal dikarenakan mereka masih sedikit bingung dengan penjelasan materi pada media tersebut. Selain itu, siswa juga kurang teliti dalam menjawab soal, yakni dalam menentukan daerah hasil (range) sehingga titik yang diinginkan pun tidak sesuai, dan berakibat grafik fungsinya tidak sesuai yang diharapkan. Namun, secara umum mereka sangat senang dan antusias dalam belajar menggunakan media $A l$ Barik (Tutorial Gambar Grafik). Menurut mereka, belajar dengan menggunakan media tersebut sangat bermanfaat, meskipun di satu sisi mereka juga menginginkan media tersebut dalam bentuk aplikasi di android agar lebih praktis digunakan.

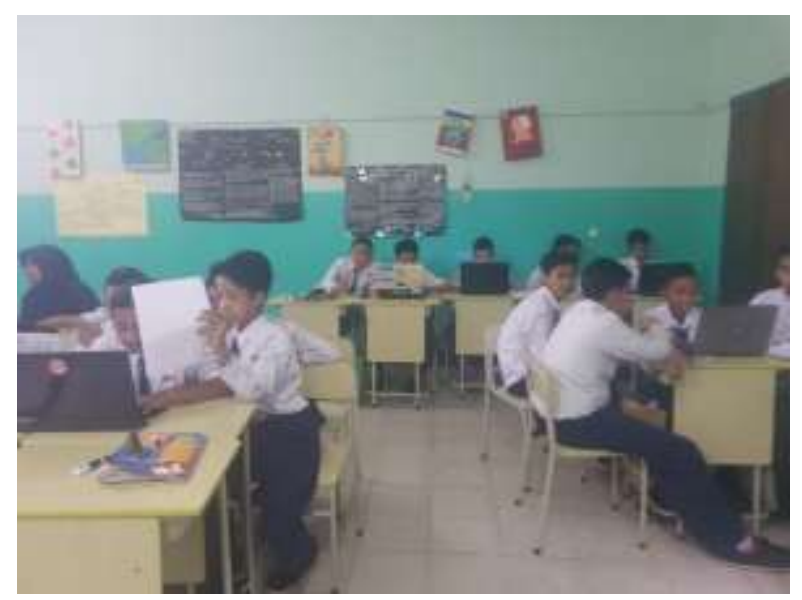

Gambar 7. Siswa berkelompok menggunakan media Al Barik (Tutorial Gambar Grafik)

Setelah di-review ulang oleh beberapa ahli, media Al Barik (Tutorial Gambar
Grafik) juga masih terdapat kekurangan, diantaranya materi yang disajikan masih belum cukup untuk menjadikan siswa belajar mandiri dan membangun pemahamannya sendiri (konstruktivistik), atau dengan kata lain pembelajaran pada materi Fungsi dan Persamaan Garis Lurus dengan menggunakan media $A l$ Barik (Tutorial Gambar Grafik) masih cenderung mengarah pada teori belajar behaviouristik. Meski demikian, secara keseluruhan, media Al Barik (Tutorial Gambar Grafik) yang dikembangkan mendapatkan penilaian dan tanggapan yang baik dari para ahli, praktisi/guru, maupun siswa.

Sebagaimana dibahas sebelumnya, proses belajar mengajar pada hakekatnya merupakan proses komunikasi, yakni penyampaian pesan dari pengantar ke penerima (Sanjaya, 2012; Daryanto, 2010; Munadi, 2013). Oleh karena itu, diperlukan alat bantu penyampaian pesan tersebut, yakni media pembelajaran yang digunakan oleh guru untuk menyampaikan atau menyalurkan pesan (materi pelajaran) kepada siswa (Asyhar, 2012; Rusman, 2012), sekaligus sebagai alat untuk merangsang pikiran, perasaan, perhatian dan minat siswa untuk belajar. Selain itu, media pembelajaran juga turut mempengaruhi iklim, kondisi, dan lingkungan belajar yang ditata dan diciptakan oleh guru. 
Penggunaan media pembelajaran dalam proses belajar mengajar, khususnya media tutorial ataupun video dapat membangkitkan keinginan dan minat yang baru, membangkitkan motivasi dan rangsangan kegiatan belajar, membantu smeningkatkan pemahaman, serta menyajikan materi secara menarik dan terpercaya (Arsyad, 2011; Sari, Saputro, \& Hastuti, 2014). Sehingga, dengan belajar menggunakan media pembelajaran, maka waktu yang digunakan untuk memainkannya tidak akan terbuang siasia.

Beberapa kajian penelitian juga menunjukkan dampak positif dari pemanfaatan articulate storyline dalam pembelajaran. Melalui media interaktif melalui tutorial yang dikembangkan, diharapkan dapat meningkatkan respon siswa terhadap kegiatan belajar mengajar di kelas. Sebagaimana diungkapkan oleh Seels \& Glasglow (Yumini \& Rakhmawati, 2015) mengungkapkan bahwa media pembelajaran interaktif adalah suatu sistem penyampaian pengajaran yang menyajikan materi video rekaman dengan pengendalian komputer kepada siswa yang tidak hanya mendengar dan melihat video dan suara, tetapi juga memberikan respon yang aktif, dan respon itu yang menentukan kecepatan dan sekuensi penyajian.
Selain itu, pada penelitian yang dilakukan oleh Robertson \& East, diperoleh hasil bahwa secara konvensional, hanya $32 \%$ siswa mencapai skor bagus, dan rata-rata lebih dari $10 \%$ mengulangi tugas yang sama. Dengan menggunakan software articulate storyline hanya 5\% siswa yang gagal ulangan dan 95\% siswa menunjukkan keterampilan yang ditetapkan di dalam kurikulum (Yumini \& Rakhmawati, 2015). Sehingga, pemanfaatan komputer dalam dunia pendidikan merupakan suatu keniscayaan, dimana akan memberikan berbagai dampak yang positif dalam proses pembelajaran.

Adapun pengembangan media pembelajaran media $A l$ Barik (Tutorial Gambar Grafik) tentunya tidak terlepas dari konstruksi beberapa teori belajar yang digunakan, seperti : a) teori behaviouristik, yakni digunakannya konsep stimulasi, respon, faktor penguatan (reinforcement), serta umpan balik (feedback) (Warsita, 2008), b) teori psikologi kognitif, yakni mencakup penggunaan daya ingat, motivasi, pikiran, dan refleksi siswa (Rusman, 2012), c) teori konstruktivisme, yakni siswa aktif mencari tahu dan membangun pengetahuan untuk membuat pengertian yang mereka pahami (Rusman, 2012), yang berarti bahwa pembentukan konsep dibangun sendiri oleh siswa melalui kegiatan yang merangsang 
ide/gagasan cemerlang berkaitan dengan suatu konsep, atau dengan kata lain siswa sendiri yang bertanggung jawab atas peristiwa belajar dan hasil belajarnya pahami (Rusman, 2012; Warsita, 2008).

\section{Kesimpulan}

Berdasarkan hasil penelitian dan pembahasan yang telah dikemukakan, maka dapat disimpulkan bahwa media $A l$ Barik (Tutorial Gambar Grafik) yang dikembangkan sebagai media pembelajaran untuk mengatasi kesulitan siswa Sekolah Menengah Pertama dalam pembelajaran Aljabar memenuhi kriteria valid Valid dengan rata-rata persentase $87,35 \%$, Praktis dengan persentase 81,53\%, dan Efektif dengan sumbangan keberhasilan penggunaan media tersebut pada uji coba sebesar 90,83\% (skala kecil) dan 88,13\% (skala besar). Selain itu, berdasarkan capaian hasil belajar siswa juga menunjukkan rata-rata di atas 75 , meskipun terdapat 3 siswa pada uji coba skala besar yang skor pencapaiannya tepat di angka 75, Dengan demikian, media $A l$ Barik (Tutorial Gambar Grafik) dapat dikatakan layak digunakan sebagai media pembelajaran matematika SMP.

\section{Pustaka}

Arikunto, S. 2010. Prosedur Penelitian: Suatu Pendekatan Praktik.
Yogyakarta: Rineka Cipta.

Arsyad. 2011. Media Pembelajaran. Jakarta: PT. Raja Grafindo Persada. Asyhar, R. 2012. Kreatif Mengembangkan Media Pembelajaran. Jakarta: Referensi.

Darmawan. 2012. Pendidikan Teknologi Informasi dan Komunikasi. Bandung: PT. Remaja Rosdakarya.

Daryanto. 2010. Media Pembelajaran. Yogyakarta: Gava Media.

Farihah, U. 2015. Pengaruh Program Interaktif Geogebra Terhadap Motivasi dan Hasil Belajar Siswa Pada Materi Grafik Persamaan Garis Lurus. Jurnal Pendidikan Dan Pembelajaran Matematika (JP2M), 1(1), 11-23.

Kachepa, A., \& Jere, N. 2014. Implementation of Mobile Games for Mathematics Learning: a Case of Namibian Schools. Sept, 5(5), 7.

Kholifah, N., \& Santosa, A. B. 2016. Pembelajaran Menggunakan Software Articulate pada Mata Pelajaran Elektronika Dasar Kelas X TAV di SMK Negeri 1 Madiun. Jurnal Pendidikan Teknik Elektro, 5(1), 265-270.

Munadi. 2013. Media Pembelajaran; Sebuah Pendekatan Baru. Jakarta: Referensi.

Narullita, D., \& Masduki. 2016. Kesulitan Siswa dalam Menyelesaikan Masalah Fungsi. In Konferensi Nasional Penelitian Matematika dan Pembelajarannya (KNPMP I) Universitas Muhammadiyah Surakarta (pp. 164-171). Surakarta: Universitas Muhammadiyah Surakarta.

Pratama, R. A.(2017. GAMBAR (Game Aljabar) in Learning Algebra. In ICONS-CHARACTER

DEVELOPMENT IN THE 21 CENTURY EDUCATION (pp. 866875). Yogyakarta: Universitas PGRI Yogyakarta. Retrieved from http://icons.upy.ac.id/2017/11/16/ga mbar-game-aljabar-in-learning- 
algebra/

Purnama, \& Asto. 2014. Pengembangan

Media Pembelajaran Interaktif

Menggunakan Software Articulate

Storyline pada Mata Pelajaran Teknik

Elektronika Dasar Kelas X TEI 1 Di

SMK Negeri 2 Probolinggo. Jurnal

Pendidikan Teknik Elektro, 3(2), 275-279.

Puspitasari, \& Hardini. 2012. Strategi

Pembelajaran Terpadu (Teori,

Konsep, Implementasi). Yogyakarta:

Familia.

Rusman. 2012. Belajar dan Pembelajaran

Berbasis

Komputer :

Mengembangkan Profesionalisme

Guru Abad 21. Bandung: Alfabeta.

Sanjaya. 2012. Perencanaan dan Desain

Sistem Pembelajaran. Jakarta:

Kencana Prenada Media Grup.

Sari, K. W., Saputro, S., \& Hastuti, B. 2014. Pengembangan Game Edukasi Kimia Berbasis Role Playing Game (RPG) pada Materi Struktur Atom sebagai Media Pembelajaran Mandiri untuk Siswa Kelas X SMA di Kabupaten Purworejo. Jurnal Pendidikan Kimia (JPK), 3(2), 9798.

Serin, O. 2011. The Effects of The Computer Based Instruction on The Achievement and Problem Solving Skills of The Science and Technology Students. The Turkish Online Journal of Educational Technology, 10(1), 184.

Setyosari, P. 2013. Metode Penelitian Pendidikan dan Pengembangan. Jakarta: Kencana Prenada Media Grup.

Sugiyono. 2016. Metode Penelitian Kuantitatif Kualitatif dan $R \& D$. Bandung: Alfabeta.

Warsita. 2008. Teknologi Pembelajaran: Landasan dan Aplikasinya. Jakarta: Rineka Cipta.

Yumini, S., \& Rakhmawati, L. 2015. Pengembangan Media Pembelajaran Berbasis Flipbook Maker pada Mata Pelajaran Elektronika Dasar di SMK
N 1 Sampang. Jurnal Pendidikan

Teknik Elektro, 5(1), 83-88. 
